\title{
An interdisciplinary adventure into the worlds of teaching and practical theology
}

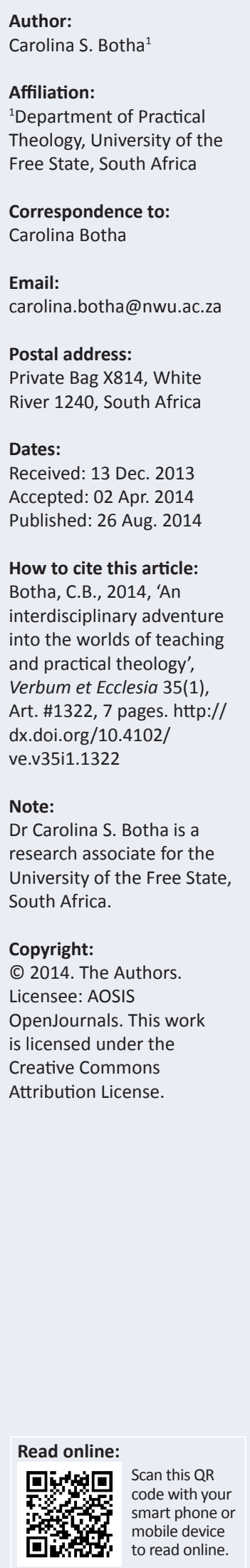

A constant challenge to researchers and academic scholars in practical theology is to stay relevant and up to date with the constantly evolving academic concepts in which they discourse. These interactions between individuals and intellectual fields often allow for what Julian Müller terms a 'moment of praxis' within their epistemology that functions as a meeting place between different ideas, paradigms and often even different academic disciplines.

Intradisciplinary and/or interdisciplinary implications: This article investigated the possibility of creating an interdisciplinary epistemology between practical theology and teaching. By exploring the role that postfoundationalist discourse and interdisciplinary conversations can play in identifying and addressing challenges which face teaching, new light can be shed on the relationship between teaching and practical theology which thus highlights correlations between these two relevant fields.

The human mind, once stretched by a new idea, never regains its original dimensions. (Oliver Wendell Holmes)

\section{Introduction \\ Meandering between two worlds}

I am a practical theologian. I am also a high school teacher. Therefore I am constantly attempting a balancing act between these worlds. The aim of this article is to address the similarities and differences between the practical realities of these two domains. The article will thus explore the often modernist, almost rigid routine of teaching versus the postmodern and dynamic opportunities offered by the world of practical theology. Defining my epistemology within these totally different mind sets is an adventure and often a road not yet paved.

It would be easy to assume that there were not many common denominators between the worlds of education and that of practical theology. The social construction discourse, however, advocates the making of new meaning and the authoring of alternative stories. The foundation of the social construction discourse is that people and societies construct the lenses through which they interpret the world (Hoffman 1990:2). These provide the looking glass through which people choose the beliefs, practices, words and experiences that make up their lives and constitute their selves. This implies that all aspects of a person, their beliefs, values and commitments are situated in various historical, political, social and cultural contexts from which they will interpret the world.

The social construction discourse thus offers me the freedom to structure my thinking, understanding and functioning within the worlds of teaching and practical theology in a way that suits my personal needs and expectations. Using this reasoning as building blocks to my own road offers me the freedom not to be restrained by the modernistic approach often connected to teaching, or to be pressured into being more involved in the academic world of research. In a similar way, postfoundationalist thinking also promotes an alternative view on praxis, truths, hermeneutics and lived religion. Hereby people are validated in their quest to merge such worlds. I am authentic in my search for a symbiosis between my life as a teacher and my work as a practical theologian.

After reading the work of Van Huyssteen (2006) and Müller (2009), I came to the realisation that I could not continue my own academic discourse without offering a primary voice to the postfoundationalist paradigm. Within the postfoundationalist hypothesis there is believed to be space for a certain degree of overlap between the disciplines of teaching and practical theology and thus the opportunity for the creation of new knowledge and experiences. 
In addition, the postfoundationalist approach to practical theology, although also hermeneutical in nature, moves beyond mere hermeneutics. It is more reflexive and situationally embedded in epistemology and methodology. The father of this paradigm, Van Huysteen (1999), captures its essence in the following way:

\begin{abstract}
A postfoundationalist theology wants to make two moves. First, it fully acknowledges contextuality, the epistemically crucial role of interpreted experience, and the way that tradition shapes the epistemic and non-epistemic values that inform our reflection about God and what some of us believe to be God's presence in this world. At the same time, however, a postfoundationalist notion of rationality in theological reflection claims to point creatively beyond the confines of the local community, group, or culture towards a plausible form of interdisciplinary conversation. (p. 4)
\end{abstract}

There is indeed room for different paradigms and contexts within my epistemology. I have the freedom to adapt my thinking to the specific context in which I find myself, because my thinking is dynamic and dependent on the various situations in which I operate. I realised that not only was the world of practical theology evolving, but my own understanding thereof was growing and developing as I was becoming more comfortable in my own academic skin. The freedom to move transversally between different disciplines has strengthened the interdisciplinary relationship between teaching and practical theology. It is, however, not a merger that happens without growing pains or challenges. This article will shed light on the concepts of postfoundationalist thinking and interdisciplinary conversations. The challenges to postfoundational discourse in the world of practical theology will be discussed and special reference will be made to the practical implications of these challenges in the world of teaching. The merger between practical theology and teaching is thus explored and the hidden potential within this collaboration is highlighted.

\section{Postfoundationalist discourse}

As neither the attributes of traditional foundationalism nor those of nonfoundationalism seemed to meet the unique needs of the practical theological discourse, Van Huyssteen (1999:113) proposes a postfoundational approach that fully acknowledges and respects the role of context, the crucial input of interpreted experience and the significance of discourses and traditions in shaping religious values. He further argues against the isolation of theology in a pluralist world and advocates a postfoundationalist notion of rationality that embraces the postmodern, multidisciplinary nature of theology (Van Huyssteen 2000:428-429) and thus places theology in conversation with other academic disciplines.

Such a postfoundationalist notion of reality enables people to communicate across boundaries and move transversally from one discipline to another, from one tradition to the next and also from context to context. This evolution has started and developed from a real and local narrative. In other words, the rationality that unfolded was situational and contextual. The dialogue that was initiated was not based on abstract ideas and concepts, but on real-life situations where people searched for a safe public space to do theology. Van Huyssteen (2000) elaborates:

Each of our domains of understanding may indeed have its own logic of behaviour, as well as an understanding unique to the particular domain, but in each the rich resources of human rationality remain. When we discover the shared richness of the resources of rationality without attempting to subsume all discourses and all communities under one universal reason, we have discovered the richness of a postfoundationalist notion of rationality. (p. 239)

\section{Transversal rationality}

The notion of 'transversal rationality' is a proposal by Schrag (2006:19), Van Huyssteen (2000:427) and others to better articulate what a postfoundationalist rationality would look like in practice. Transversal reasoning involves identifying places in time and space where concepts, ideas and disciplines intersect. For example, in Alone in the World?, Van Huyssteen's (2006) book based on his Gifford lectures, he examines the question of human uniqueness as a transversal concern that is addressed in various scientific disciplines, including theology and practical theology.

Richard Osmer (2006) also explores the potential contribution of Van Huyssteen's transversal model of interdisciplinarity to practical theology. He characterises contemporary practical theology as a discipline that:

investigates [Christian] praxis empirically, interprets it to better understand and explain its patterns, constructs a theological framework with which it can be assessed critically, and provides practical models and guidelines for its future conduct and reform. (Osmer 2006:339-342)

This creates the way towards providing a responsible and workable interface between theology and other disciplines and the emergence of new voices. It sets the scene for the development of alternative forms of consciousness, the enhancement of metaphors that embody the transversality and the merger of different stories and disciplines. Rationality in a postfoundationalist sense is attentiveness to the rational account of what people believe and how they think and act accordingly. This rationality describes the dynamic interaction of various dialogues with one another - as a form of transversal reasoning that justifies and urges an acknowledgement of multiple interpretations as one moves across borders and boundaries. Through transversal reasoning, this rationality provides a common ground for communication between people, systems and disciplines that have different beliefs, cultures and academic viewpoints. This is very relevant in teaching where different views, religions and cultural backgrounds need to be merged in order for teachers and a school to create a system of communication and caring that encompasses all these different entities. 
Postfoundational rationality is not only based on our own experiences, but is also capable of reaching beyond that. It starts with an individual but also extends to communities and aims towards acknowledging these shared and interpreted experiences on an interpersonal and social level (Müller 2011). Just as all scientific observations are theory-laden, so all religious experiences are interpretationladen and this elucidation provides valid religious meaning (Van Huyssteen 1997:19-20). Agreeing with Van Huyssteen, Schrag (2006:25) asserts that interpretation is called upon both in scientific discovery and humanistic inquiry. It cuts across the culture spheres of science, morality, art, and religion'. These interpretations are received because they are socially constructed, as opposed to an individual or subjective construction, and emphasise the contribution of tradition, culture and societal discourses to the interpretation (Müller 2004:297).

\section{Interdisciplinary conversations}

\author{
Van Huyssteen (2006) claims that a:
}

postfoundationalist approach helps us realize ... that we are not the intellectual prisoners of our contexts or traditions, but that we are epistemically empowered to cross contextual, cultural, and disciplinary borders to explore critically the theories, meanings, and beliefs through which we and other construct our worlds. (p. 25)

This freedom offers the opportunity to facilitate conversations that accommodates two or more disciplines to ensure '... the borrowing of concepts, methods and techniques of one science by another and the integration of these elements into the other science' (Van Wyk 1997:78) can be achieved. De Lange (2007:50) points out that approaching the challenge of interdisciplinarity from such a postfoundationalist approach holds a number of advantages:

- Human rationality cannot be claimed by one academic discipline only.

- It is possible for different disciplines and reasoning strategies to be linked together on an equal footing.

- By taking into consideration our traditional and cultural scientific rationality in both theology and science, we can strive towards a multidisciplinary epistemology.

- Postfoundationalist thinking provides a space in which the epistemological overlaps in the theological and scientific dialogue can be promoted.

- A postfoundational approach to interdisciplinarity can be viewed as non-hierarchical in that no one discipline with its principles and practices can claim an absolute or foundational position over the other (Van Huyssteen 2006:41).

Van Huyssteen (2006) summarises this line of thinking when he concludes that:

interdisciplinary discourse, then, is an attempt to bring together disciplines or reasoning strategies that may have widely different points of reference, different epistemological foci, and different experiential resources. This 'fitting together', however, is a complex, multileveled transversal process that takes place not within the confines of any given discipline ... but within the transversal spaces between disciplines. (p. 9)

Interdisciplinary conversations are a means of solving problems and questions that cannot be addressed by singular methods and implies an understanding of epistemologies and methodologies of both disciplines involved. They can also be viewed as part of a traditional search for wide-ranging knowledge. Paradoxically, at the same time, they represent a 'radical questioning of the nature of knowledge itself and our attempts to organize and communicate it' (Moran 2002:15). Furthermore, interdisciplinarity brings together the products of focused enquiry to uncover new and broader patterns. It is democratic, dynamic and mutual in its attempts to forge connections across different disciplines. It also implies selfreflexivity and occupies what Moran (2002:15) calls the 'undisciplined space in the interstices between disciplines ... [that attempts] to transcend disciplinary boundaries'. It is always transformative, seeking to produce new forms of knowledge in its interaction with different disciplines.

According to Van Huyssteen (1999:35, 2000:428), these interactions result not only in the cross-disciplinary breakdown of traditional boundaries between scientific rationality and other forms of rational inquiry. They are also involved in the inevitable move from being objective spectators to being participants or agents in the very activities that were initially thought to be observed objectively.

Lastly, it is essential to keep in mind that ethics and epistemology should not be separated in the dialogue between theology and science. This underlines the assumption that knowledge cannot be separated from its contexts and traditions. Postfoundationalism in theology and science will therefore be held together by one overriding concern: whilst we always come to our interdisciplinary conversations with strong beliefs, commitments and even prejudices, postfoundationalism enables us to at least acknowledge epistemologically these strong commitments and identify the shared resources of human rationality in different modes of reflection. Subsequently, a person will then aim to reach beyond the walls of their own epistemic communities in cross-contextual, cross-cultural and crossdisciplinary conversations.

\section{A relational approach}

In order for me to place myself firmly within a postfoundationalist frame of mind whilst thinking in an interdisciplinary way, it is important to understand the basic relationship between foundationalist and nonfoundationalist ideas, a postfoundationalist approach and interdisciplinary conversations. Table 1 offers a summary on the premises of each of the approaches, the key aspects thereof and the practical implication of an interdisciplinary way of working.

Yet, as exciting as the concept of interdisciplinary thinking may be in terms of creating a space for different voices and 
TABLE 1: Summary of epistemological approaches.

\begin{tabular}{|c|c|c|c|}
\hline Epistemology & Premises & Rationality & Interdisciplinary conversations \\
\hline Foundationalist & $\begin{array}{l}\text { - Fixed truths. } \\
\text { - Meta-narratives. } \\
\text { - Modernistic approach. }\end{array}$ & $\begin{array}{l}\text { - Universal rationality - universal and } \\
\text { fixed knowledge is the ultimate frame of } \\
\text { reference. } \\
\text { - Dangers - approach is rigid and } \\
\text { inflexible. }\end{array}$ & $\begin{array}{l}\text { - Ideas from other disciplines are considered } \\
\text { a threat. } \\
\text { Meta-narratives cannot be altered or } \\
\text { adapted. }\end{array}$ \\
\hline Nonfoundationalist & $\begin{array}{l}\text { - No privileged knowledge. } \\
\text { - Postmodern approach. } \\
\text { - Meaning is created within a } \\
\text { specific relativistic context. }\end{array}$ & $\begin{array}{l}\text { - Multiversal rationality - meaning is a } \\
\text { product of diversity and experienced } \\
\text { realities. } \\
\text { - Dangers - approach is too relativistic and } \\
\text { subjective. }\end{array}$ & $\begin{array}{l}\text { - Difficult because everything is relative and } \\
\text { subjective. } \\
\text { - No tentative boundaries in found and } \\
\text { differences be compared. }\end{array}$ \\
\hline Postfoundationalist & $\begin{array}{l}\text { - Removed epistemology from the domain } \\
\text { of abstract justification of knowledge } \\
\text { and relocated it in the sphere of socially } \\
\text { constructed knowledge in a specific and } \\
\text { local context. }\end{array}$ & $\begin{array}{l}\text { - Transversal rationality - identifying places } \\
\text { in time and space where different concepts, } \\
\text { ideas, disciplines, etc. intersect. } \\
\text { - Dangers - easy to disregard the input of the } \\
\text { participants to the story whilst moving from } \\
\text { the local to the global. }\end{array}$ & $\begin{array}{l}\text { - Local or concrete account of the ways } \\
\text { particular disciplines and persons intersect } \\
\text { one another, overlapping in some ways and } \\
\text { diverging in others. } \\
\text { - Including as many voices as possible } \\
\text { to ensure authenticity in covering all } \\
\text { the aspects of the participants' lived } \\
\text { experience. }\end{array}$ \\
\hline
\end{tabular}

Source: Botha, C.S., 2012, 'High school teachers as agents of hope: A practical theological engagement', PhD dissertation, Department of Practical Theology, University of the Free State

different contexts, this way of thinking is filtered through with the challenges that modernist discourse still presents. It is therefore important to acknowledge such challenges in order to work towards dynamic growth and movement within practical theology and teaching.

\section{Challenges to postfoundationalist and interdisciplinary thinking}

One of the aspects most worthy of attention in Van Huyssteen's (2000) proposition is his claim that part of what it means to be rational is to be engaged in a public, critical dialogue with others, both within and across contextual boundaries. This means that theology can actually only claim to be rational when it is interdisciplinary. Although much effort has gone into the integration of interdisciplinary thinking into the conceptualisation of practical theology, I am still not convinced whether the current paradigms for interdisciplinary theological method can fully account for a dynamic relationship.

With respect to interdisciplinary methods, I kept asking myself why almost all the literature I read referred only to the interaction with science. I wondered why the philosophy of social sciences has not yet been engaged as seriously as Van Huyssteen (1999) has considered the contribution of the philosophy of the natural sciences.

I wonder how Van Huyssteen's (1999) postfoundational rationality can allow us to think about the ways in which theology can engage in a dialogue with disciplines other than natural sciences, such as education, arts, cultural studies, political theory, economics, sociology, feminist theory and mathematics. In such a way we can incorporate rationality into a larger, more flexible framework that can account for a wider array of disciplines, voices, perspectives, contexts and concerns. In addition to moving beyond 'abstract' discussions and focusing on specific topics, I would like to see more explorations of how thoughts on education and being a teacher could inform this dialogue. Considering my situation as a teacher, I found myself pondering whether teaching could then be equated to science? Was the gap between theology and science larger and more significant than the space between theology and teaching?

As part of his work with HIV and AIDS, Julian Müller (2004) identifies a second challenge facing the use of a postfoundationalist approach. This approach is mostly focused on contextuality and on listening to people's incontext experiences; as such, the question needs to be asked whether a postfoundationalist approach will guarantee such an inclusion of the in-context experiences in the formulation of interpretations that are made. The postfoundationalist process does require committed listening to the in-context experiences of people, but is it also committed to the inclusion of an individual's own understanding of his or her own story?

If I aim to consider my life in an accountable way and with integrity, I have to include hermeneutics and social constructionism as part of the process. Whilst hermeneutics and postfoundationalist thinking provide me with a good epistemological basis and even methodological direction, I need to turn to the social construction discourse to guarantee the inclusion of all possible stories. The danger exists that even transversal rationality can then become just another universal truth. Looking back now, I realise that it is not methodology or transversal rationality that creates limitations in the postfoundationalist discourse. The limitations are created by our own short-sightedness in the way we approach conversations and the assumptions and conclusions at which we so easily arrive. It would be easy to revert back to a modernistic perspective of looking at all teachers in the same way and somehow see myself as being different. In doing that, I might just be undermining the value of such an interdisciplinary approach.

If I can achieve a symbiotic relationship between practical theology and teaching through a postfoundationalist paradigm and in an ethical way, I have the potential of maintaining an interdisciplinary dialogue. Including others in this discourse could mean a doing of theology that takes the social constructions of the local seriously, yet can move beyond the local into a global dialogue without recourse to 
universal foundations. The merger of the lived experiences and individual stories of teaching and practical theology can contribute to moving the contextual boundaries that prevent interdisciplinary conversations and further open up space for individuals stories of the praxis of teachers, allowing them to be heard on an equal footing to the theories that give substance to that which we believe.

\section{Challenges in the context of teaching}

In the context of this article, teaching is considered as all the tasks performed by teachers in South African schools. This includes the hours they spend in the classroom, their extracurricular responsibilities, as well as all other interaction they have with individual children and groups. As mentioned earlier, the flexible nature of the postfoundationalist discourse makes it difficult to pin down and give it a specific placement within the practical theology. This same argument can be made for teaching. Owing to the multitude of tasks that teachers undertake and the many different roles they play, there are a variety of contexts in which teaching takes place.

As a result of the significance of such context when work is undertaken in these fields, it is crucial to remember that as soon as a context changes, new challenges are presented that practical theologians and teachers have to address. In his article, 'Theology in a postmodern context: Ten challenges', Rossouw (1993:894-907) identifies ten challenges created by this paradigm shift within the practical theology. I found myself wondering how many of these challenges have been met in the 19 years since this article has been written. Although practical theologians might have been working for almost two decades to overcome and conquer these challenges, the present context of teaching in South Africa still resonates with most of these challenges as first listed by Rossouw. I also had to wonder how it still echoes within my context as a teacher and how it therefore translates into the educational framework and the context of this research. In this way, Rossouw's article stays very relevant, regardless of the age thereof.

A postfoundational approach to practical theology opens up a line of thinking where the progress that practical theology has made in resolving these challenges can provide teachers, and the greater field of education, with tools to address their own challenges. The postmodern approach to thinking further reminds me that we can never reach a place of equilibrium where we do not have any challenges facing practical theology and teaching as individual fields or in the interface between these two academic disciplines. Table 2 therefore critically reflects on the initial ten challenges set by Rossouw in the current context of the merger between the worlds of teaching and practical theology in South Africa. The table offers a bird's eye view of the individual challenges that will be deconstructed and conceptualised in greater detail throughout the rest of this article.

\section{An ordinary theology of human praxis}

... and for me practical theology is all about risk. Practical theology, in my mind, is daring to believe that life and not theory is where the theological enterprise begins ... The only potential for the future of Christian faith lies in the doing, the going, the practice. A practical theology is not the taking of theology and applying it to a certain situation, but rather it is a beginning. (Taylor 2007:204)

Working towards resolving these challenges and aiming towards the doing of practical theology within a participatory approach reaches beyond a mere practice of theology. Practical theology becomes a social construct within religious groups and these communities thus become the author of theology in their local context. This dynamic form of theology proceeds and grows from life and from action, placing the practice of concrete people at the centre of its workings and reflections.

In times of increasingly complex social problems, such as poverty, neglect and abuse, cooperation between different disciplines in education has become indispensable. Therefore, all disciplines, including (and especially) theology, are compelled to adapt their practices to be interdisciplinary, multiperspective and cooperative. This is also true of the practice of practical theology within schools. Because schools, and by implication teachers, are forced to act as primary educators for the children they encounter, practical theology is becoming increasingly relevant in schools. Socioeconomic problems, the need for emotional and psychological support and even looking after physical needs such as food and housing, have become part of the job description of teachers. Seeing themselves as practical theologians thus enables teachers to complete these tasks in a caring and sensitive manner.

A Christian teacher will always contemplate how religion can primarily be carried out and promoted as an explicit and implicit reality in schools and their structures. Schools then become a high quality place of learning and living. My classroom is not only a place to practice my Christian principles, but also the laboratory of my own discipline. Teachers are blessed and burdened by the knowledge that everything they do in the classroom, from how they establish a learning environment to how they help the class negotiate conflict between learners with diverse experiences and perspectives, is a teaching about the praxis of theology.

\section{Conclusion}

I believe that the time has come to formally question the parallels between the discipline of practical theology and that of education, to actively become part of the interdisciplinary dialogue between these two fields. What are the points of contact between the church and schools as communities of faith? How do Christian teachers approach their subject matter? What is distinctive about schools with Christian 
TABLE 2: Ten challenges to practical theology.

\section{Rossouw's ten challenges for practical theology}

Critical self-reflection - To stay accountable for your thoughts and actions.

Being involved in the debate about moral issues - Postmodern discourse opens up space for new narratives and debate where the stories of both sides of a moral issue can be heard.

Working towards a spirituality of wholeness - Postmodern discourse is a holistic endeavour that aims towards transformation in communities, rather than only transforming individual lives.

Working towards a new style of communication - Honouring the social construction of language where words and symbols can have multiple meanings.

Aiming towards a theology built on narratives - Creating space where individual stories can be validated and authenticated.

Building character - A migration from asking 'what we believe' to 'who we are', a move from meta-theories and methodologies to a search for personal agency.

Towards understanding the marginalised - Giving a voice to the silenced and repressed in our societies.

Seeing faith as personal but not private - Postmodern discourse opens up space for person's own story with God but still considers it to be part of the social construction of religion.
These challenges applied in the teaching context

- Teachers should be accountable and transparent about their motivation fo staying in teaching, their stress levels and the role that Christianity plays in their lives at school.

- They need a platform where they can share their frustrations, where they can self-reflect and voice their concerns and share in the experiences, joys and challenges that other teachers face.

- Throughout this process of sharing, teachers need to always stay accountable and transparent about their thought processes and the emotions that underline these experiences.

- In a modernistic society parents were the primary educators and schools were merely responsible for the intellectual development of children. In a postmodern world there has been a shift towards parents and society looking towards schools and teachers to be the primary educators of their children.

- Teachers now have to balance their academic workload and the extra responsibility of educating children about moral issues, relationships and about life.

- Furthermore, teachers need to educate themselves on current issues and debates around morality and ethical issues. By being informed and involved in conversation on such matters, teachers equip themselves to handle questions conversation on such matters, teachers equip themselves
and situations where these topics are being discussed.

- If schools are responsible for more than only imparting academic knowledge, they are also responsible for the emotional health and spiritual well-being of children and teachers.

- The challenge lies in creating a community of care where teachers not only care for children, but care for themselves, their colleagues and ultimately care for children, but care for themselves, their colleagues and ultimati community projects and services is becoming increasingly evident.

- It is therefore imperative that teachers actively take part in the process of transformation and development in their local communities.

- It is challenging for teachers to find time to search for opportunities in a busy school system to create space for individual stories and to validate local knowledge in order to promote the development of alternative stories.

- Given the already mentioned opinion that teachers are expected to act as primary educators to the children they teach, the need for teachers to become more personally involved in the lives of their learners is paramount.

- Very often the teacher is the only person that a child will trust enough and confide in about fears, expectations or even dreams and achievements that they might set for themselves.

- Teachers are tasked with learning to communicate on different levels. They have to acknowledge that language carries meaning and that they have the responsibility to also listen for the not-yet-said.

- It is crucial that teachers refine their communication skills and that they have an acute awareness that their words carry meaning that imprints on the lives of the children they teach. Both the compliments and the harsh words that teachers say to children can have long-term influences on the childrens' futures.

- This is also relevant to teachers hearing a cry for help that is often not said in so many words, or even hearing the words that they do not dare speak about their own emotional state.

- Postmodern discourse encourages the move away from the generic definition of a teacher and the conventional roles that the secular world expects them to play towards a new understanding and spiritual characterisation and identity of being a teacher.

- The political identity of teachers can very often stand in direct conflict with the personal identity that they have created for themselves. An understandin of their own epistemology and a very clear perception of what they stand for can help teachers to merge these two demanding identities.

- Many teachers need a constant reminder that the needs of children are becoming increasingly more demanding and that many children consider school the only safe space they have.

- Teachers are also burdened with giving themselves and their colleagues a voice in a society where they are easily overlooked or bombarded with a voice in a society where they

- Acting as a community of care for themselves and for the children they teach Acting as a community of care for themselves and for the children they teach
can create a safe space where teachers can move from feeling marginalised and silenced towards a place of empowerment.

- A postmodern line of thinking encourages teachers to critically evaluate that which Government and the powers that be promote as truths and rules to which Government and the powers that be promote as truths and rules to thoughts, decisions and actions.

- Many teachers struggle to align their own ethical beliefs and integrity with that what is demanded of them. Teachers need to be accountable for their own moral compass and be prepared to defend their choices and actions.

- Teachers need to choose to be practical theologians in their classrooms and to turn their religion into praxis in their professional as well as their personal lives. Their career then awards them the opportunity to actively live out their faith.

- Being transparent about their Christianity offers teachers the opportunity to be practical theologians in their classrooms.

- However, the opposite also needs to be considered - acting as a practical theologian for learners of a different religion, might even say more about the social construction of caring and Christianity.

Re-discovering of own identity - Identity is constructed in context as people progress through life. The postmodern discourse promotes the notion that there is no distinction between the knower and the known, but that they are interactive and inseparable.
The challenge is to find the time and the energy for teachers to create alternative stories of their own identity as a teacher and to merge that with the story of their relationship with children, colleagues, family and especially with God.

- Teachers need to pay more attention to their own emotional state. They should self-care and thus ensure that they can optimally function in their role as teachers. 
teachers and what might they have to contribute to the understanding and conceptualisation of practical theology? How do they act as practical theologians in their classrooms or on the sports field? What urges them to live out their faith and be a moral compass for the children with whom they work? Are they aware of the fact that they are practicing as practical theologians or do they simply feel that they are 'doing their job'? How does their identity as a Christian teacher influence their work ethic and the way that they approach conflict and stress? How many of them consider their career in teaching to still be a calling from God?

As I contemplated these questions, I found myself wondering whether it was possible to learn something through comparing literature on practical theology to what people actually do in classrooms and why they do it. Astley (2002:47) argues that there is a lot in 'ordinary belief' that is 'worthy of theological attention'. He refers to the dogma and theologising of Christians who have received little or no theological education of a 'scholarly, academic or systemic kind' (Astley 2002:56), as ordinary theology.

I also resonate with the postulations of Hunt (1991), Cobb (1993) and Astley (2002:52), where they consider a theology that is grounded in the challenges of ordinary life, rather than only in the sphere of the academy. I concur that the ultimate object of theology, God, and its product, faith, are not necessarily better known by the 'experts' than by those 'who do their theology outside the academia' (Astley 2002:52). Furthermore, the actions described by the experts are often irrevocably part of the job description of the ordinary child of God. Therefore, my own identity as practical theologian and as teacher can find an equal voice embedded in the social construction discourse and the postfoundationalist way of working; I can work creatively within the working paradigms of both theology and teaching. With this in mind, suddenly, the challenges facing education look less daunting and the inability to put into words exactly where I fit within the academic landscape, becomes less important. What becomes relevant is the freedom to live out a theology of praxis in my classroom and in my life that is not structured by modernistic rules and guidelines, but rather built upon my own epistemology and theoretical placements.

\section{Acknowledgements Competing interests}

The author declares that she has no financial or personal relationships that may have inappropriately influenced her in writing this article.

\section{References}

Astley, J., 2002, Ordinary theology: Looking, listening and learning in theology, Ashgate, Burlington.

Botha, C.S., 2012, 'High school teachers as agents of hope: A practical theological engagement', PhD dissertation, Department of Practical Theology, University of the Free State.

Cobb, J.B., 1993, Becoming a thinking Christian, Abingdon Press, Nashville.

De Lange, M.C., 2007, 'Reflections on methodology and interdisciplinarity in the postmodern dialogue between theology and the natural sciences', Acta Theologica 2, 44-62.

Hoffman, L., 1990, 'Constructing realities: An art of lenses', Family Process 29(1), 1-12. $\mathrm{http}: / / \mathrm{dx}$.doi.org/10.1111/j.1545-5300.1990.00001.x

Hunt, M.E., 1991, Fierce tenderness: A feminist theology of friendship, Crossroad, New York.

Moran, J., 2002, Interdisciplinarity: The new critical idiom, Routledge, New York.

Müller, J.C., 2004, 'HIV/AIDS, narrative practical theology, and postfoundationalism: The emergence of a new story', HTS Teologiese Studies/Theological Studies 60(1\&2), 293-306.

Müller, J.C., 2009, 'Transversal rationality as a practical way of doing interdisciplinary work with HIV and Aids as a case study,' Practical Theology in South Africa 24(2), 199-228.

Müller, J.C., 2011, '(Outo) biografie as teologie', HTS Teologiese Studies/Theological Studies 67(3), 1-5, viewed 22 September 2012, from http://www.hts.org.za/ index.php/HTS/article/view/1113/1941

Osmer, R., 2006, 'Toward a transversal model for interdisciplinary thinking in practical theology', in F. leRon Shults (ed.), The evolution of rationality. Interdisciplinary essays in honour of J. Wentzel van Huyssteen, pp. 327-345, W.B. Eerdmans, Grand Rapids.

Rossouw, G.J., 1993, 'Theology in a postmodern culture: Ten challenges', HTS Teologiese Studies/Theological Studies 49(4), 894-907. http://dx.doi. org/10.4102/hts.v49i4.2528

Schrag, C.O., 2006, Traces of rationality: Acknowledgment, recognition, and repetition, in F. leRon Shults (ed.), The evolution of rationality, pp. 19-29, W.B. Eerdmans, Grand Rapids.

Taylor, C., 2007, A secular age, Harvard University Bellknap Press, Cambridge.

Van Huyssteen, J.W., 1997, 'Should we be trying so hard to be postmodern? A response to Drees, Haught and Yeager', Zygon Journal of Religion and Science 32(4), 567-584. http://dx.doi.org/10.1111/0591-2385.00112

Van Huyssteen, J.W., 1999, The shaping of rationality. Toward interdisciplinary in theology and science, W.B. Eerdmans, Grand Rapids.

Van Huyssteen, J.W., 2000, 'Postfoundationalism and interdisciplinarity: A response to Jerome Stone', Zygon Journal of Religion and Science 35(2), 427-439. http:// dx.doi.org/10.1111/0591-2385.00285

Van Huyssteen, J.W., 2006, 'Alone in the world? Human uniqueness in science and theology', The Gifford Lectures, W.B. Eerdmans, Grand Rapids.

Van Wyk, A.G., 1997, "Theology" and interdisciplinary co-operation with other sciences', Practical Theology in South Africa 12(2), 75-86. 